\title{
Pemikiran Johan Galtung tentang Kekerasan dalam Perspektif Feminisme
}

\section{Linda Dwi Eriyanti}

Program Studi IImu Hubungan Internasional, Universitas Jember, Jalan Kalimantan No. 37, Kampus Tegalboto, Jember, Jawa Timur 68121 Email: linda.fisip@unej.ac.id

Diserahkan: 30 Juli 2017, diterima: 19 September 2017

\begin{abstract}
This article aims to analyze the gender aspects in Johan Galtung thought about Violence. Johan Galtung conception of violence, namely, direct violence, structural violence, and cultural violence was comprehensive enough to observe violence at all levels, including gender-based violence. The issue of violence appeal to feminists because of violence against women is a mechanism of subordination of women. Violence against women has an impact not only for women victims but also women in general, which ultimately in the lives of women always feel threatened by numerous acts of violence in public and private sphere. Using the sociology of knowledge, this article seeks the connection between Johan Galtung's thought and his life background. The research method is a qualitative method with literature study used secondary data. This article found that there are similarities between Johan Galtung thought with numerous streams of feminism that ever existed. Telling about direct violence, Johan Galtung puts women at enmity with men on one hand. On the other hand, the structure and culture of patriarchy that have existed in society also become violent themselves. In its efforts to realize peace, Johan Galtung wants the equality between the sexes, where there are cooperation and a balance of roles between men and women who all of them lead to the peace process. Keywords: Johan Galtung's Thought, Violence, Feminism, Peace
\end{abstract}

\begin{abstract}
Abstrak
Artikel ini bertujuan untuk menganalisa aspek gender dalam pemikiran Johan Galtung tentang kekerasan. Konsep kekerasan Johan Galtung yang meliputi kekerasan langsung, kekerasan struktural, dan kekerasan kultural, cukup komprehensif untuk melihat kekerasan di semua tingkat, termasuk kekerasan berbasis gender. Isu kekerasan menarik bagi feminis karena kekerasan terhadap perempuan merupakan mekanisme subordinasi perempuan. Kekerasan terhadap perempuan tidak hanya berdampak pada korban, tapi juga perempuan pada umumnya, yang pada akhirnya dalam kehidupan perempuan selalu merasa terancam oleh berbagai tindakan kekerasan di ranah publik dan privat. Dengan menggunakan sosiologi pengetahuan, artikel ini mencoba menganalisis hubungan antara Johan Galtung dan latar belakang kehidupannya. Metode penelitian yang digunakan adalah metode kualitatif, dengan studi literatur menggunakan data sekunder. Penelitian ini menemukan bahwa ada kesamaan antara pemikiran Johan Galtung dengan berbagai aliran feminisme yang pernah ada. Berbicara tentang kekerasan langsung, Johan Galtung menempatkan perempuan berhadapan dengan laki-laki yang merupakan pelaku kekerasan. Di sisi lain, struktur dan budaya patriarki yang ada di masyarakat juga merupakan bentuk kekerasan, di mana struktur yang keras, dilegitimasi oleh budaya kekerasan menciptakan lingkungan yang penuh kekerasan. Dalam upayanya mewujudkan perdamaian, Johan Galtung menginginkan persamaan antara jenis kelamin, di mana ada kerjasama dan keseimbangan peran antara pria dan wanita yang semuanya mengarah pada proses perdamaian.
\end{abstract}

Kata Kunci: Pemikiran Johan Galtung, Kekerasan, Feminisme, Perdamaian

\section{PENDAHULUAN}

Johan Galtung menjadi salah satu pemikir penting di abad ini terkait dengan berbagai tulisannya tentang perdamaian dan kekerasan. Karyanya menjadi rujukan para akademisi, NGO, pembuat kebijakan, bahkan politisi di banyak negara. Pemikiran Galtung yang terinspirasi dari Mahatma Gandhi berkontribusi dalam upaya mewujudkan perdamaian yang menurutnya bukan hanya sekedar nega-

tive peace, tetapi juga positive peace. Konsep kekerasan dari Johan Galtung yang melingkupi kekerasan langsung, kekerasan struktural, dan kekerasan kultural penting untuk mengidentifikasi sumber kekerasan beserta dampaknya, sehingga memungkinkan untuk mencari solusi yang lebih komprehensif. Konsep kekerasan Johan Galtung telah diterima secara luas dalam Studi Perdamaian (Salmi, 


\section{3:141-153; Bufacchi, 2005:193-204).}

Johan Galtung menjadi pengajar studi perdamaian di berbagai universitas. Galtung juga menjadi negosiator dalam sejumlah konflik internasional, juga aktif terlibat sebagai fasilitator resolusi konflik, misalnya antara Korea Utara dan Korea Selatan, Israel, dan Palestina di wilayah Teluk, juga bekas Negara Yugoslavia. Upayanya di bidang kemanusiaan dan perdamaian memberinya banyak penghargaan. Johan Galtung menerima Right Livelihood Award, penghargaan alternatif yang mengimbangi Penghargaan Nobel, pada tahun 1987. Tahun 1988 ia menerima Norwegian Humanist Prize, pada ada tahun 1990 ia menerima Socrates Prize for Adult Education dan Bajay International Award for Promoting Gandhian Values pada tahun 1993. Ia juga menerima gelar Doktor Honoris Causa dan Profesor Kehormatan dari sedikitnya 15 universitas terkemuka di dunia, yang diterimanya mulai tahun 1975 .

'Segitiga Kekerasan' yang diungkapkan Johan Galtung, yaitu kekerasan langsung, struktural, dan kultural, membantu untuk mengidentifikasi bentuk-bentuk kekerasan. Kekerasan langsung bisa terlihat secara nyata demikian pula dengan pelakunya. Kekerasan struktural melukai kebutuhan dasar manusia, tetapi tak ada pelaku langsung yang bisa diminta tanggung jawabnya. Sementara kekerasan kultural adalah legitimasi atas kekerasan struktural maupun kekerasan langsung secara budaya (Galtung, 1990: 291-305).

Feminisme adalah gerakan pembebasan perempuan yang tujuan akhirnya adalah tatanan kehidupan yang adil dan manusiawi. Pemikiran Galtung terkait kekerasan berkontribusi terhadap gerakan kaum feminis dalam upaya untuk menumbuhkan kesadaran akan adanya kekerasan, penindasan, dan ketidakadilan terhadap perempuan, serta adanya tindakan sadar yang dilakukan baik oleh laki-laki maupun perempuan untuk mengubah keadaan tersebut untuk mewujudkan perdamaian. Isu kekerasan menjadi penting bagi kaum feminis, karena selama ini kekerasan yang menimpa perempuan, berupa penyiksaan, pemerkosaan, kekerasan domestik, pelecehan seksual, merupakan mekanisme yang memproduksi subordinasi perempuan oleh laki-laki (Pilcher \& Whelehan, 2004:173). Permasalahan yang akan dibahas dalam artikel ini adalah, bagaimana aspek gender dalam pemikiran Johan Galtung tentang kekerasan dilihat dengan perspektif feminis?

\section{KERANGKA PEMIKIRAN}

Untuk melihat pemikiran Johan Galtung, penulis merasa perlu melihat latar belakang kehidupannya. Karena pemikiran seseorang sudah tentu dipengaruhi oleh situasi di mana dan di saat seseorang hidup. Untuk itu penulis menggunakan sosiologi pengetahuan, yakni cabang sosiologi yang mempelajari hubungan antara pengetahuan dan masyarakat yang fokus kajiannya adalah kondisi sosial dan kondisi eksistensial dari pengetahuan, terutama yang menyangkut eksistensi sosiologis dari pengetahuan dan masyarakat.

Mannheim menjelaskan bahwa sosiologi pengetahuan berguna untuk menjelaskan persoalan-persoalan, gagasangagasan, atau pemikiran-pemikiran yang bersifat sosial atau eksistensial. Pengetahuan dan gagasan selalu dipengaruhi oleh faktor tempat di mana pengetahuan itu ada, meskipun pada tingkatan yang berbeda-beda dalam struktur sosial dan proses sejarah. Gagasan-gagasan atau ide-ide yang menyebar di masyarakat selalu merujuk kepada struktur sejarah dan struktur sosial yang memandang sesuatu dengan menggunakan perspektif tertentu (Coser, 1971: 431).

Sosiologi pengetahuan digunakan dalam artikel ini untuk menelusuri latar belakang pemikiran, pemahaman, serta teori yang dihasilkan oleh Johan Galtung. Johan Galtung sebagai seorang pemikir dan aktifis perdamaian memiliki kesadaran akan pilihan-pilihan dalam hidupnya, yang dipengaruhi faktor eksternal maupun internal. Rangkaian dialektis dalam proses eksternalisasi, obyektifikasi, dan internalisasi, yang berpengaruh terhadap pembentukan pemikiran manusia, bisa dijelaskan dengan melihat masyarakat sebagai produk individu, juga masyarakat sebagai realitas obyektif, serta bahwa individu adalah produk masyarakat. Masyarakat yang merupakan produk individu menjadi kenyataan obyektif melalui proses eksternalisasi, sebaliknya individu produk masyarakat melalui proses internalisasi (Nur Syam, 2005: 37-38). 


\section{PEMBAHASAN}

\section{LATAR BELAKANG PEMIKIRAN JOHAN GALTUNG TENTANG KEKERASAN}

Johan Galtung yang seorang aktifis perdamaian, mau tidak mau selalu bersentuhan dengan banyak kasus kekerasan. Dari banyak kasus kekerasan itulah Johan Galtung merasa perlu memikirkan kembali perlunya memasukkan dimensi gender dalam upaya mewujudkan perdamaian. Kekerasan berbasis gender terjadi di seluruh dunia, dalam situasi tidak ada perang dan bahkan lebih banyak lagi dalam situasi konflik. Kekerasan berbasis gender, yang korbannya mayoritas adalah perempuan, muncul dalam wujud yang beragam. Gagasan gender sebagai konstruksi sosial menjadi salah satu unsur yang mewujudkan hubungan kekuasaan di masyarakat. Lebih jauh, pemahaman tentang gender yang patriarkis bisa menjadi kunci untuk produksi dan reproduksi kekerasan di semua tingkatan.

Hingga usia 81 tahun, Galtung telah memiliki pengalaman lebih dari 50 tahun melihat bagaimana perempuan dan laki-laki secara berbeda berhubungan dengan isu-isu perdamaian dan keamanan; dalam politik formal dan informal, dalam mediasi dan pelatihan mediasi, dalam operasi penjaga perdamaian, dan dalam pertemuanpertemuan. Dia menyatakan:

"Sangat banyak proses perdamaian yang ada di dunia dilakukan di pundak perempuan...dan yang terpenting dalam negosiasi perdamaian adalah peran perempuan yang mampu dengan cara holistik, dialektis, memiliki empati tinggi dan kasih sayang, antikekerasan, lebih suka dialog, mampu menangani konflik, dan menciptakan perdamaian dengan cara yang kreatif (Galtung, 2009).”

Johan Galtung bekerja di puluhan universitas dan lembaga penelitian, diantaranya di Oslo, Dubrovnik, Berlin, Santiago, Princeton, Jenewa, Hawaii, Kyoto, Schlaining, Witten/Herdecke, dan lain-lain. Ia mendirikan International Peace Research Institute, Oslo (PRIO) pada tahun 1959 dan Journal of Peace Research pada tahun 1964. Saat ini Galtung juga menjadi konsultan dari berbagai Badan PBB seperti UNESCO, UNCTAD, WHO, ILO, FAO, UNU, UNEP, UNIDO, UNDP, UNITAR, dan UNRISD.

Banyak pemikiran Johan Galtung yang terinspirasi dari
Mahatma Gandhi. Galtung yang saat itu masih berusia 17 tahun menangis mendengar kematian Gandhi yang disebutnya sebagai fisik yang jenius.

"Gandhi memberi kita hadiah yang tidak ternilai, satyagraha, yakni berpegang teguh pada satya. Bagi Gandhi satya adalah esensi menjembatani konsep Tuhan, Cinta, dan Kebenaran, menyatukan spiritual, emosional, dan kognitif-tidak menempatkan mereka dalam ruang yang terpisah seperti yang kita lakukan di Barat, yang menyingkirkan dua hal tersebut dari penelitian dan ilmu pengetahuan "(Galtung, 2007).

Galtung mengaku mendapat pelajaran penting, bahwa kekerasan yang membunuh dengan cepat melalui peluru ataupun membunuh secara perlahan melalui kelaparan dan penyakit adalah sama jahatnya. Galtung optimis kekerasan dapat dihapus bila kita mengetahui penyebabnya. Dia mengaku belajar dari Gandhi tentang strukturalisme, bahwa yang menjadi penyebab kekerasan adalah struktur yang salah dan bukannya aktor yang jahat. Dikatakannya non-violence adalah non-kooperasi dengan struktur yang salah dan pada saat yang sama mengusulkan dan membuat struktur alternatif (Mas'oed dalam Windhu, 1992).

\section{KEKERASAN MENURUT JOHAN GALTUNG}

Kekerasan dalam arti luas dikatakan Galtung, sebagai sesuatu penghalang yang seharusnya bisa dihindari yang menyebabkan seseorang tidak bisa mengaktualisasikan diri secara wajar. Penghalang tersebut menurut Galtung sebenarnya dapat dihindarkan, sehingga sebenarnya kekerasan itu juga bisa dihindari jika penghalang itu disingkirkan (Muchsin, 2006).

"Singkatnya, kekerasan adalah setiap kondisi fisik, emosional, verbal, institusional, struktural atau spiritual, juga perilaku, sikap, kebijakan atau kondisi yang melemahkan, mendominasi atau menghancurkan diri kita sendiri dan orang lain" (Galtung, 1971).

Kekerasan langsung bisa bermacam-macam bentuknya. Dalam bentuk yang klasik, ia melibatkan penggunaan kekuatan fisik, seperti pembunuhan atau penyiksaan, pemerkosaan dan kekerasan seksual, juga pemukulan. Kekerasan verbal, seperti penghinaan, secara luas juga 
diakui sebagai kekerasan (Galtung, 1971).

Johan Galtung menggambarkan kekerasan langsung sebagai:

“...gangguan yang harusnya dihindari terkait dengan

kebutuhan dasar manusia, kebutuhan untuk hidup layak, sesuatu yang menurunkan tingkat kepuasan kebutuhan riil di bawah potensi yang ada. Ancaman penggunaan kekerasan juga merupakan kekerasan." (Galtung, 1990: 291-305).

Selain kekerasan langsung, Galtung menekankan bentuk lain dari kekerasan, yaitu kekerasan struktural, yang tidak dilakukan oleh individu tetapi tersembunyi dalam struktur yang lebih kecil maupun lebih luas. Penetrasi, segmentasi, marginalisasi dan fragmentasi, sebagai bagian dari eksploitasi merupakan komponen penguat dalam struktur yang berfungsi menghalangi formasi dan mobilitas untuk berjuang melawan eksploitasi. Pertama, penetrasi menanamkan pandangan tertentu kepada kelompok lemah, dikombinasikan dengan segmentasi yang memberikan pandangan yang sangat parsial atas sesuatu yang sedang terjadi. Selanjutnya marginalisasi menjaga kelompok yang lemah tetap berada di luar batas yang ditetapkan, dikombinasikan dengan fragmentasi untuk menjaga agar sang underdog tetap berjauhan satu sama lain. Keempat hal tersebut beroperasi dalam konteks gender - bahkan ketika perempuan tidak selalu memiliki tingkat kematian dan kesengsaraan yang lebih tinggi. Dan sebenarnya perempuan bisa jadi memiliki tingkat harapan hidup lebih tinggi dari laki-laki, jika mereka bisa menghindarkan diri dari aborsi akibat seleksi jenis kelamin, pembunuhan bayi, dan kerentanan terhadap kematian pada masa kanak-kanak (Galtung, 1996: 199).

“... Aspek-aspek budaya, lingkungan simbolik dimana kita berada, seperti agama-agama dan ideologi, bahasa dan seni, ilmu pengetahuan empiris dan ilmu formal (logika, matematika) - yang dapat digunakan untuk membenarkan atau melegitimasi kekerasan langsung atau kekerasan struktural."(Galtung, 1996:196).

Galtung mendefinisikan kekerasan kultural sebagai sikap yang berlaku dan keyakinan kita yang telah diajarkan sejak kecil dan mengelilingi kita dalam kehidupan sehari- hari tentang kekuasaan dan kebutuhan kekerasan. Lebih mengingat cerita sejarah yang mengagungkan catatan dan laporan perang maupun kemenangan militer daripada cerita pemberontakan tanpa kekerasan ataupun kemenangan melalui koneksi dan kolaborasi. Hampir semua budaya mengakui bahwa membunuh seseorang adalah pembunuhan, namun membunuh puluhan, ratusan atau ribuan selama terjadinya konflik yang dideklarasikan, disebut 'Perang' (Galtung, 1971).

\section{PEMIKIRAN JOHAN GALTUNG DAN FEMINISME}

Berbicara tentang kekerasan, dalam banyak hal, pemikiran Johan Galtung sejalan dengan pemikiran kaum feminis radikal. Galtung mengklaim patriarki sebagai kekerasan langsung, struktural dan kultural. Patriarki membuat dikotomi antara peran publik dan privat, produktif dan reproduktif, yang membentuk relasi kuasa yang timpang antara laki-laki dan perempuan. Tubuh perempuan merupakan objek utama penindasan oleh kekuasaan laki-laki. Tubuh serta hak-hak reproduksi, seksualitas, seksisme, relasi kuasa perempuan dan laki-laki, dan dikotomi privat-publik menjadi fokus permasalahan.

"Banyak pria bodoh yang tidak tahu bagaimana perkosaan berdampak pada pada tubuh, pikiran, dan jiwa perempuan, sebagai trauma yang mengganggu pertumbuhan rohaninya (Galtung, 2010).

Galtung menyatakan, dengan melihat faktor biologis, kekerasan nampak tidak dapat dimodifikasi:

"Biologisme digunakan sebagai kekerasan budaya terhadap perempuan dengan melegitimasi dominasi laki-laki melalui kekuatan otot dan menunjukkan kelemahan perempuan berupa instabilitas dan kemunduran perempuan selama siklus menstruasi dan prokreasi." (Galtung, 1996: 42)

Persoalan penindasan perempuan didasarkan atas hubungan kekuasaan di mana ada kecenderungan laki-laki untuk mengontrol perempuan. Kegiatan laki-laki dilegitimasi oleh institusi masyarakat yang patriarkis. Galtung menyatakan:

"Patriarki, formasi sosial kekerasan (seperti subkultur kriminal dan struktur militer), menggabungkan kekerasan langsung, struktural dan kultural dalam segitiga setan. 
Mereka memperkuat satu sama lain dalam siklus yang dimulai dari sudut manapun. Kekerasan langsung - seperti perkosaan, mengintimidasi dan menindas; kekerasan struktural melembagakan, dan kekerasan budaya menginternalisasi hubungan itu - khususnya bagi korban, yakni perempuan, menjadikan struktur sangat kokoh." (Galtung, 1996: 40)

Galtung memberikan solusi untuk menghapuskan kekerasan berbasis gender dengan cara:

1. Meningkatkan empati laki-laki melalui pola sosialisasi yang serupa dengan sosialisasi untuk perempuan. Dari sudut pandang untuk mengurangi kekerasan, kesamaan antar gender tidak boleh dengan membesarkan anak gadis seperti laki-laki, juga tidak boleh menaikkan keduanya di posisi antara, tetapi dengan membesarkan anak laki-laki seperti anak gadis dan menjadikan ayah lebih mirip ibu dalam bidang yang secara psiko-fisiologis sangat penting. (Galtung, 2010: 46).

2. Ada kemungkinan untuk memperpanjang hubungan ibu dengan anak laki-laki di mana perempuan memahami tugas untuk menghumaniskan laki-laki. (Galtung, 2010: 46).

Laki-laki dan perempuan memang berbeda, namun demikian tidak berarti perbedaan itu membuat perempuan berada pada posisi tertindas. Selama ini asumsi yang dibuat oleh laki-laki yang dijadikan pedoman untuk menilai perempuan. Galtung mendukung hal tersebut dengan menyatakan bahwa secara biologis, tingkat monoamine oxidase (MAO) berbeda antar jenis kelamin:

"Rendahnya enzim ini berkecenderungan terhadap agresi. 90\% laki-laki memiliki enzim MAO rendah, dan akan meningkat seiring meningkatnya usia, sedangkan untuk perempuan 10\% memiliki MAO rendah. MAO menyebabkan kehancuran metabolik amines, khususnya amines biogenik yang dianggap sebagai komponen kritis dalam patogenesis berbagai gangguan psikotik. Tingkat MAO yang rendah berarti berkurangnya kemampuan untuk amines biogenik, dengan demikian memungkinkan bagi gangguan psikotik tertentu. Kekerasan dapat dilihat sebagai pra-psikotik atau psikotik, yang menunjukkkan gangguan serius dibawah kesadaran." (Galtung, 1996: 43)
Sejalan dengan kaum feminis liberal, Galtung juga menginginkan perempuan memiliki peran di ruang publik. Namun demikian mereka berbeda, di satu sisi feminis liberal mengklaim peran publik tersebut sebagai hak dan karena perempuan memiliki potensi yang sama dengan laki-laki, Galtung justru melihat perbedaan antara laki-laki dan perempuan itu yang membuat perempuan harus memiliki peran di ruang publik. Galtung menyebutkan salah satu peran perempuan itu diperlukan dalam upaya mewujudkan perdamaian:

"Pengalaman konkret saya menunjukkan bahwa perempuan jauh lebih kuat dalam semua aspek manusia dan karena alasan itu juga perempuan bisa menjadi pekerja perdamaian yang lebih baik." (Galtung, 2004: 67)

Sedangkan dengan feminis posmodern, yang menyebut bahasa menjadi salah satu penyebab opresi terhadap perempuan karena seksisme bahasa sebagai upaya memuliakan laki-laki dan mengesampingkan, menyepelekan ataupun menghina perempuan, Galtung juga menyatakan bahwa salah satu unsur kekerasan budaya adalah bahasa, di mana sebenarnya perempuan bisa keluar dari kekerasan budaya khususnya bahasa tersebut.

"Gerakan penting untuk penulisan non seksis adalah salah satu contoh yang baik tentang transformasi kultural untuk menghindari kekerasan kultural." (Galtung, 1996: 204.

205)

Berbicara tentang Feminis Marxis-Sosialis, Galtung pernah menyatakan feminisme telah memberikan kontribusi besar dalam upaya mereduksi kekerasan. Feminis menyumbang dengan membuat patriarki terlihat dengan jelas, mengingatkan pada fokus Marxis pada struktur yang menghubungkan sarana dan mode produksi (Galtung, 2010).

"...dengan mengidentifikasi patriarki sebagai pola dasar

kapitalisme dan militerisme. Dari sudut patriarki perdamaian negatif adalah kombinasi yang sangat kejam antara kekerasan langsung, kekerasan struktural, dan kekerasan kultural: merugikan dan menyakiti, membunuhmengalahkan, semua jenis ketidakadilan yang mengarah ke segala macam ketidaksetaraan, dan pembenaran, dan 
beberapa di antaranya bersumber dari tafsir kitab suci."

(Galtung, 2010).

Peminggiran perempuan adalah suatu hal esensial bagi kapitalisme (Galtung, 2010:181). Aturan baru bagi lakilaki dan perempuan tercipta ketika kekuatan kapitalis memberikan batas antara tempat kerja dan rumah, mengirim laki-laki sebagai tenaga kerja primer, keluar menuju tempat kerja dan memenjarakan perempuan, sebagai tenaga kerja sekunder, di rumah.

Sejalan dengan ekofeminisme, Galtung yakin bahwa peran utama perempuan akan membawa dunia pada perdamaian, jauh dari kekerasan dan perang. Juga dalam perang melawan kejahatan sosial lain seperti perbudakan, kolonialisme, penghancuran alam, segregasi, patriarki.

Galtung menempatkan alienasi sebagai bagian dari kekerasan struktural, sebagaimana ekofeminisme menjelaskan orang dalam patriarki kapitalis cenderung untuk teralienasi dari segala sesuatu: produk dari kerja mereka, alam, satu sama lain, dan bahkan dirinya sendiri, yang mengakibatkan manusia berperilaku aneh (Galtung, 2010: 392).

Galtung juga setuju dengan ekofeminisme mengklaim bahwa orang-orang dalam patriarki kapitalis, terutama lakilaki yang karena alienasi mereka dari alam cenderung lebih besar daripada yang dialami perempuan, ingin lebih dekat dengan alam, tetapi tidak tahu caranya (Mies, 1993). Galtung menyatakan:

"Laki-laki juga menginginkan cinta, keintiman, belaian, kehangatan, perawatan dan kebaikan, seperti halnya perempuan, anak-anak, dan orang tua. Tetapi cinta pada laki-laki begitu dibayangi oleh kebencian patriarki, sehingga akhirnya hanya kebencian yang dirasakan banyak laki-laki." (Galtung, 2010).

\section{MENEMPATKAN PEMIKIRAN JOHAN GALTUNG}

\section{Kekerasan Langsung: Laki-laki vs Perempuan}

Johan Galtung mempunyai perhatian khusus terhadap kekerasan berbasis gender dengan menyebut perkosaan dan penyerangan seksual, intimidasi, menindas, sebagai bagian dari kekerasan langsung. Aktifitasnya sebagai peneliti dan mediator perdamaian, membuatnya melihat fakta bahwa fenomena kekerasan langsung adalah fenomena laki-laki, di mana hampir semua kekerasan dilakukan oleh laki-laki dan menjadikan perempuan sebagai korbannya. Kekerasan yang menimpa perempuan adalah langsung dan pribadi, yang bisa dialami perempuan yang berada di ruang publik maupun di ranah domestik.

"Banyak faktor yang mendukung perang, tiga di antaranya adalah patriarki, sistem negara dengan memonopoli kekuasaan dan sistem negara atau superpower dengan monopoli tertinggi di tangan penguasa. Laki-laki lebih cenderung pada kekerasan daripada perempuan."

(Galtung, 1996:5).

Kekerasan langsung adalah sebuah fenomena laki-laki (Galtung, 1996: 88-89). 95\% kekerasan langsung dilakukan oleh laki-laki dan terdapat kekerasan langsung laki-laki yang masif pada semua tingkat sosial, sebagai kekerasan kriminal dalam keluarga dan masyarakat, dan sebagai kekerasan politik di dalam dan antara masyarakat satu dengan masyarakat lainnya (Galtung, 1996: 90-91).

Meskipun perempuan seringkali menjadi korban kekerasan yang dilakukan oleh laki-laki, dengan adanya struktur dan kultur pro kekerasan di masyarakat, perempuan sendiri akhirnya merasa kekerasan sebagai sesuatu hal yang tidak bisa dihindari. Bahkan kemudian para perempuan menjadi korban kesekian kalinya dari kekerasan laki-laki, di mana perempuan terpaksa ikut melestarikan budaya kekerasan dan bahkan menjadi pelaku kekerasan terhadap perempuan lain, untuk kepentingan laki-laki.

"Perempuan seringkali terlibat dalam kekerasan verbal daripada kekerasan fisik,...apa yang orang marjinal (perempuan) lakukan (berupa tindakan kekerasan) adalah untuk membela diri mereka sendiri." (Galtung, 2000: 860-872).

Galtung memilah kekerasan yang dilakukan oleh lakilaki dan perempuan dengan mencontohkan kekerasan yang menimpa perempuan dengan menunjuk data statistik Swedia yang menyebut 1400 kasus perkosaan dan 14.000 kasus kekerasan dalam rumah tangga, selama satu tahun dalam populasi sekitar 8 juta, di mana angka sebenarnya tentu lebih besar. Secara umum dia membuat standar 25:1, antara laki-laki dan perempuan pelaku kekerasan kriminal, dan dalam kasus kekerasan seksual jelas laki-laki 
menempati posisi lebih tinggi (Galtung, 2000: 41).

Dikatakannya, laki-laki melakukan kekerasan di semua tingkatan sosial, berupa kekerasan kriminal dalam keluarga dan masyarakat, juga sebagai kekerasan politik di dalam dan di antara masyarakat yang satu dengan yang lainnya. Bahkan Galtung menyebut perempuan yang turut serta dalam aktifitas kekerasan politik dan terorisme, juga disebabkan oleh pengaruh laki-laki, dan sebenarnya perempuan tetaplah sebagai korbannya. Demikian pula ketika perempuan terlibat dalam pasukan militer dan menjadi tentara, laki-lakilah yang memberikan perintah untuk melakukan kekerasan, bahkan pembunuhan (Galtung, 1996).

\section{Patriarki: Kekerasan Struktural dan Kekerasan Kultural}

Dengan konsepsi kekerasan struktural dan kekerasan kultural Johan Galtung, patriarki bisa dilihat sebagai penyebab utama terjadinya kekerasan. Patriarki menempatkan laki-laki dengan maskulinitasnya pada posisi dominan dan perempuan dengan femininitasnya dalam posisi subordinat.

"Patriarki sebagai institusionalisasi dominasi laki-laki dalam struktur vertikal, dengan korelasi sangat tinggi antara posisi dan gender yang dilegitimasi oleh kebudayaan, dan sering muncul sebagai kekerasan langsung dengan laki-laki sebagai subyek dan perempuan sebagai obyek." (Galtung, 1996: 40).

Eksploitasi merupakan bagian utama kekerasan struktural. Struktur patriarkis jelas menempatkan laki-laki pada posisi atas, dan karenanya ia mendapatkan keuntungan substansial dari posisinya tersebut. Penetrasi, segmentasi, marginalisasi dan fragmentasi, beroperasi dalam konteks gender, di mana sebenarnya perempuan berpotensi untuk memiliki harapan hidup sama atau bahkan lebih tinggi dari laki-laki. Potensi ini bisa terwujud jikalau perempuan bisa menghindarkan diri dari aborsi akibat seleksi jenis kelamin, pembunuhan bayi, dan kerentanan terhadap kematian pada masa kanak-kanak (Galtung, 1996:199).

Patriarki sebagai kekerasan kultural membentuk sikap yang berlaku dan keyakinan yang telah diajarkan sejak manusia lahir dan mengelilingi manusia dalam kehidupan sehari-hari tentang kekuasaan dan kebutuhan kekerasan (Galtung, 2000: 41). Kekerasan kultural ini membuat kekerasan langsung dan struktural terlihat sebagai sesuatu benar atau setidaknya tidak salah. Mekanisme psikologisnya dapat berupa internalisasi. Salah satu cara kekerasaan kultural berjalan dengan cara mengubah warna moral suatu aksi dari merah/salah menjadi hijau/benar atau sekurangkurangnya kuning/dapat diterima, misalnya membunuh atas nama negara adalah benar sedangkan membunuh atas nama pribadi adalah salah. Cara lain adalah dengan mengaburkan realita, dengan demikian kita tidak melihat aksi atau fakta kekerasan, atau setidaknya bukan sebagai satu kekerasan (Galtung, 1996: 198).

Menggabungkan konsepsi kekerasan Johan Galtung dengan manifestasi ketidakadilan gender yang dialami oleh perempuan yang diilustrasikan oleh Mansour Fakih (2008), penulis memetakan bentuk-bentuk kekerasan yang dialami perempuan terkait dengan struktur dan kultur patriarki di antaranya adalah:

1. Kekerasan langsung terhadap perempuan, berupa kekerasan fisik dan psikologis yang dirasakan secara langsung oleh perempuan, berupa penyiksaan, serangan seksual, pelacuran, pornografi, pemaksaan KB, dan trafficking.

2. Kekerasan struktural dan kultural yang berwujud:

a. Beban ganda perempuan

Pemilahan ranah publik dan privat, di mana perempuan ditempatkan di ruang privat dan laki-laki di ruang publik, terkait dengan biologisme laki-laki dan perempuan. Peran perempuan di dalam rumah membuat perempuan menjadi memiliki penilaian menyeluruh terhadap berbagai hal, dan memiliki dialektika konsep realita yang tinggi, lebih memahami lingkungan, dan tidak hanya terfokus pada salah satu aspek saja. Hal ini membuat perempuan lebih dekat dengan alam, aspek biologis, dan organis, yang membentuk perempuan lebih peduli, feminin, dan kurang suka berkompetisi (Galtung, 1986). Namun demikian kenyataannya perempuan harus menjalankan peran di ruang publik, berupa peran kemasyarakatan, dan bagi perempuan tertentu, mereka juga harus mencari nafkah untuk keluarganya.

b. Marginalisasi perempuan

Perempuan memiliki peluang yang lebih kecil untuk 
bisa mengakses sumber daya ekonomi, berupa modal, pasar, kredit, juga fasilitas untuk pengembangan lifeskill perempuan. Oleh karenanya perempuan menjadi miskin, dan eksploitasi terhadap perempuan masif seiring dengan globalisasi saat ini.

c. Subordinasi perempuan

Perempuan berada dalam posisi subordinan, dalam keluarga, di masyarakat, maupun sebagai warga negara. Hal ini berdampak kepada perempuan yang akhirnya tidak bisa memutuskan banyak hal, bahkan yang terkait dengan dirinya sendiri. Ditambah lagi dengan kebijakan negara yang juga menempatkan perempuan sebagai obyek, karena dalam proses perumusannya hanya melibatkan sedikit perempuan, bahkan terkadang tidak dilibatkan sama sekali.

d. Stereotype terhadap perempuan

Johan Galtung melihat posisi perempuan dalam budaya yang bersumber dari keyakinan-keyakinan tertentu selalu tidak menguntungkan. Perempuan dianggap bernilai negatif dari sudut pandang agama (Galtung, 1996: 202). Posisi itu diperparah dengan adanya bahasa yang juga menjadi alat efektif untuk meminggirkan perempuan (Galtung, 1996: 205). Bahkan ilmu pengetahuan yang seharusnya bisa memposisikan semua manusia sebagai makhluk yang setara, justru menjadi alat untuk sekali lagi mengeksploitasi perempuan.

\section{BIJAK GENDER PEMIKIRAN JOHAN GALTUNG}

Terkait dengan fenomena kekerasan, Galtung lebih melihat permasalahan kekerasan sebagai permasalahan kemanusiaan secara universal. Namun demikian Galtung tidak menafikan fakta yang menunjukkan bahwa perempuan banyak menjadi korban kekerasan, baik berupa kekerasan langsung, kultural maupun struktural, meskipun tidak berarti laki-laki tidak pernah menjadi korban kekerasan.

Galtung melihat manusia yang terposisikan, baik secara kodrati atau fisiologis dan gender sebagai laki-laki dan perempuan. Dengan banyak alasan, pembedaan laki-laki dan perempuan tersebut menjadi sumber terjadinya kekerasan yang menimpa perempuan. Dengan demikian yang dibutuhkan adalah kualitas manusia, baik laki-laki maupun perempuan yang kondusif untuk mereduksi kekerasan di semua tingkatan.
Untuk memberikan solusi dalam rangka menghilangkan segala bentuk kekerasan dan mewujudkan perdamaian Galtung selalu mencari negasinya. Ketika patriarki dianggap sebagai sumber kekerasan maka yang harus dibentuk adalah paritas, yakni kesetaraan antara kedua jenis kelamin dan bukannya matriarki. Dan ketika melihat sifat feminin lebih cenderung kondusif untuk menciptakan perdamaian, maka Galtung memberikan solusi agar semua manusia memiliki sifat feminin tersebut, baik mereka yang jenis kelamin laki-laki atau perempuan.

"Perempuan berpotensi untuk bisa mengubah dunia,...

Tidak akan ada perdamaian positif, tanpa adanya

kesamaan pandangan dan kerja sama untuk saling menguntungkan antara jenis kelamin." (Galtung, 2010).

Struktur masyarakat yang patriarkis dan maskulin, bagi Galtung harus diganti dengan kesetaraan dan kerja sama antara laki-laki dan perempuan, dengan mengembangkan femininitas yang lebih kondusif untuk terwujudnya perdamaian. Dia tidak melihat semata-mata dari jenis kelamin laki-laki atau perempuan saja. Ketika laki-laki dan perempuan sama-sama memiliki potensi kekerasan, meskipun dengan tingkatan yang berbeda, sebenarnya mereka juga sama-sama berpotensi untuk menghapuskan kekerasan.

Berbicara tentang struktur negara, Galtung menyatakan keberadaan laki-laki dan perempuan berempati rendah akan berakibat sama, yakni memunculkan kekerasan di mana-mana. Dia mencontohkan Margaret Thatcher, Golda Meir, dan Indira Gandhi, yang menurutnya keberadaannya identik dengan kekerasan.

Hal tersebut akan berbeda jika dalam masyarakat dan negara dibangun struktur yang horisontal dengan ditumbuhkannya solidaritas, partisipasi, dan kerja sama, dan setiap orang bisa memahami orang lain. Semua manusia, laki-laki maupun perempuan akhirnya akan menjadi lebih humanis, di mana laki-laki tidak lagi beralasan menggunakan fisiologisnya untuk melakukan kekerasan, dan perempuan merasa nyaman dengan femininitasnya.

"Sindrom segitiga kekerasan, yakni kekerasan langsung, kekerasan struktural, dan kekerasan kultural seharusnya dikontraskan dengan sindrom segitiga perdamaian yang 
meliputi tindakan kooperatif, persahabatan, dan cinta"

(Galtung, 2010: 459).

Bagi Galtung, laki-laki dan perempuan bisa bekerja bersama menghapuskan kekerasan, baik kekerasan langsung, kekerasan dalam struktur masyarakat dan negara, maupun kekerasan kultural. Inklusifitas, saling menghargai perbedaan yang ada, kemampuan memahami orang lain, kepedulian, saling menjaga, saling mengasihi, melihat sesuatu secara holistik, menjadi hal yang penting. Dan pada dasarnya melalui sosialisasi, semua manusia, laki-laki maupun perempuan bisa memiliki sifat positif tersebut.

\section{EKLEKTISME JOHAN GALTUNG}

Johan Galtung mengadobsi perspektif feminis yang dianggapnya memiliki kelebihan dan mampu menjelaskan fenomena kekerasan yang terjadi. Di sisi lain Galtung juga tidak menutup mata terhadap kelemahan dari perspektif tersebut, sehingga dia menggunakan perspektif feminis yang lain untuk melengkapinya.

Menggunakan perspektif feminis radikal, Galtung mengidentifikasi sumber-sumber kekerasan langsung yang dikatakannya sebagai fenomena laki-laki, karena kekerasan bersumber dari laki-laki sebagai salah satu jenis kelamin biologis dengan fisiologi dan hormonal yang memungkinkan terbentuknya kekerasan dalam diri lakilaki. Dia menegaskan adanya perbedaan laki-laki dan perempuan, yang selanjutnya perbedaan itu mewujud pada perempuan memiliki lebih banyak sifat positif yang berkecenderungan pada perdamaian, dan sifat buruk lakilaki yang condong kepada kekerasan.

Nampaknya Galtung menyadari kelemahan feminis radikal, sehingga kemudian Galtung mengungkapkan bahwa sebenarnya faktor biologis hanya sedikit berpengaruh terhadap terbentuknya sifat kekerasan pada laki-laki. Faktor struktur dan kultur patriarki yang ada di masyarakatlah yang lebih dominan. Struktur dan kultur yang didominasi dan berorientasi laki-laki, dengan segala cara, telah membentuk laki-laki menyukai kekerasan.

Solusi selanjutnya untuk menghapuskan kekerasan Galtung menawarkan penghancuran patriarki untuk membentuk masyarakat yang setara antar gender:

"Kombinasi antara gender, struktur, dan perdamaian/

kekerasan membawa kita langsung ke patriarki sebagai formasi sosial. Kegagalan untuk mempersepsi realitas patriarki ke dalam masyarakat merupakan contoh yang sempurna adanya kekerasan budaya yang sedang bekerja. Konsep apapun sebaiknya dipahami dari segi negasinya, dan negasi dari patriarki bukanlah matriarki, tetapi paritas, atau persamaan struktur gender horizontal yang menghubungkan gender dalam kemitraan." (Galtung, 1996: 40).

Galtung mengambil kelebihan teori feminis sosialis yang bisa inklusif, karena menunjukkan bagaimana kekuatan seksisme dan klasisme saling terkait dalam patriarki kapitalis yang mendominasi struktur kehidupan di belahan dunia saat ini. Juga bagaimana status sosial perempuan ditentukan oleh peran produktif dan reproduktifnya. Dengan menggunakan perspektif Marxis - Sosialis, Galtung melihat struktur yang patriarkis dan kapitalis menjadikan penindasan dan kekerasan terhadap perempuan semakin masif, yang disebutnya sebagai kekerasan struktural. Struktur yang menempatkan perempuan sebagai manusia kelas dua dalam kehidupan, diperkuat dengan penempatan perempuan pada bidang kehidupan yang dianggap tidak produktif, membuat perempuan dalam bahasa Galtung, semakin teralienasi.

Perspektif feminis liberal, bagi Galtung bermanfaat untuk mendorong perempuan berpartisipasi dalam upaya mewujudkan melawan kekerasan dengan cara yang berbeda dengan yang selama ini dilakukan oleh laki-laki. Tentang kesetaraan hak seperti yang dinginkan kaum feminis liberal, Galtung juga sepakat dengan reformasi pendidikan dan hukum untuk memberikan hak yang sama bagi lakilaki dan perempuan. Disisi lain Galtung juga khawatir metode pendidikan dengan tidak menghilangkan dan mengubah pola pikir dan struktur patriarki yang sebenarnya menjadi sumber kekerasan, justru akan membuat perempuan menjadi seperti laki-laki.

Perspektif ekofeminisme membantu Galtung untuk melihat kedekatan perempuan dengan alam, yang juga membuat perempuan berbeda dengan laki-laki dalam hal femininitasnya. Galtung juga memanfaatkan kelebihan ekofeminisme yang mampu menjelaskan bagaimana semua sistem dan struktur opresi yang menimpa perempuan saling berkaitan dan saling mempengaruhi. Galtung ingin 
mengembangkan ide feminisme supaya perempuan tidak berubah menjadi seperti laki-laki, karena menurutnya perempuan memiliki keunggulan dibandingkan laki-laki dalam upaya melawan kekerasan. Galtung mengkhawatirkan fenomena perempuan yang memperjuangkan cita-cita feminisme, yakni kehidupan yang adil dan setara antar gender justru menggunakan cara-cara seperti yang dilakukan laki-laki. Dengan demikian menyebabkan peradaban modern yang ada saat ini semakin didominasi kualitas maskulin, dan yang terlihat adalah kompetisi, egoisme, dominasi dan eksploitasi, yang bermuara kepada kekerasan.

"Memerangi patriarki berarti memerangi budaya dan struktur patriarki dan sampai pada pembagian kekuasaan yang lebih adil antar gender. Bahayanya adalah, dalam proses perjuangannya, perempuan mungkin menggunakan nilai-nilai laki-laki yang mereka perangi." (Galtung, 1996: 5).

Dengan perspektif feminis posmodern, Galtung yang melihat sumber kekerasan juga berasal dari kultur yang melegitimasi kekerasan atau paling tidak membuatnya nampak seolah-olah bukan kekerasan, berharap perempuan bisa mempertahankan sifat positifnya, dan tidak harus mengikuti segala sesuatu yang selama ini ditentukan oleh laki-laki yang didasarkan pada keyakinan-keyakinan bahkan agama tertentu yang ditafsirkan secara timpang, bahkan cenderung selalu menempatkan perempuan dalam posisi yang buruk. Demikian pula halnya dengan perkembangan ilmu pengetahuan yang disosialisasikan melalui sekolahsekolah, sampai kepada universitas yang sangat maskulin, menurut Galtung akan sangat berbahaya. Perempuan yang mendapatkan pendidikan formal guna memperoleh kesetaraan justru menjadi korban dari sistem tersebut.

Dengan menggunakan beberapa perspektif feminis tersebut di atas, Galtung berupaya untuk mendapatkan gambaran secara menyeluruh tentang kekerasan yang menimpa perempuan. Setidaknya ini merupakan nilai positif di mana Galtung memberikan perhatian khusus terhadap perempuan. Seperti yang dikatakan Muthien bahwa model Galtung adalah yang paling komprehensif dalam hal inklusivitas, dia menghormati dan berkeinginan adanya keterlibatan perempuan dalam analisisnya (Muthien, 2003).

\section{KESIMPULAN}

Johan Galtung menggunakan pendekatan feminisme, yang berangkat dari perbedaan gender, dengan tidak menjadikan seksualitas sebagai satu-satunya faktor yang menentukan terbentuknya sifat kekerasan. Kekerasan bukan semata-mata milik laki-laki, perempuan juga bisa menjadi maskulin dan cenderung kepada kekerasan.

Sebagai aktifis perdamaian, Galtung juga peduli dengan kekhawatiran yang meluas di kalangan laki-laki sendiri jika ternyata perempuan yang memiliki kekuasaan akan memperlakukan laki-laki dengan cara bagaimana laki-laki memperlakukan mereka. Menurutnya yang harusnya dibenci adalah patriarki, dan bukannya laki-laki.

Upaya Galtung untuk mengintegrasikan feminisme dalam studi perdamaian sepatutnya dihargai, meskipun bagi Galtung, gender hanyalah salah satu variabel dalam analisis kekerasan. Karena sebenarnya tujuan Galtung akan adanya dunia damai bisa sejalan dengan tujuan feminisme yakni terwujudnya kesetaraan dan keadilan bagi perempuan dan laki-laki.

Kekerasan langsung, kekerasan struktural dan kekerasan kultural bisa dihapuskan dan digantikan dengan perdamaian. Jika semua orang sepakat tidak melakukan kekerasan fisik, yang di dalamnya ada kekerasan berbasis gender, maka semua orang juga akan mendapatkan perdamaian. Jika institusi di masyarakat diubah dan tidak lagi berdasarkan pada kekerasan, maka seksisme, rasisme, ageisme, klasisme, juga akan hilang dan yang muncul adalah perdamaian struktural. Demikian pula bila masyarakat tidak lagi sepakat dengan budaya kekerasan, maka yang akan terbentuk adalah budaya perdamaian. Dengan mengubah lembaga, pola pikir, dan sikap, maka kekerasan berbasis gender akan hilang dan digantikan dengan perdamaian positif yang di dalamnya terdapat harmoni dan keseimbangan.

\section{REFERENSI}

Coser, L.A. 1971. Masters of Sociological Thought: Ideas in Historical and Social Context, Harcourt Brace Jovanovich, Inc.

Fakih, Mansour. 2008. Analisis Gender dan Transformasi Sosial. Yogyakarta: Pustaka Pelajar. 
Galtung, Johan. 1969. Violence, Peace, and Peace Research, Journal of Peace Research. (online) Vol. 6, No. 3, hal. 167-191, (http://www.jstor.org/stable/422690 diakses pada 7 Februari 2011).

1971. A Structural Theory of Imperialisme, Journal of Peace Research (online) Vol 8 No 2, (http://www.jstor.org/stable/ 423477 diakses pada 7 Februari 2011).

1986. Age, Gender and Race, Nation and Class: What is The Relationship with Cosmology. Priceton, New Jersey: Center of International Studies, Princeton University.

1990. Cultural Violence, Journal of Peace Research. (online) Vol. 27, No. 3. hal. 291-305, (http://www.jstor.org/stable/ 423472 diakses pada 7 Februari 2011).

1993. Kulturelle Gewalt; in: Der Bürger im Staat 43, $2 /$

1993. p. 106, (online), (http://www.dadalos.org/ diakses pada 11 September 2010).

1996. Peace by Peaceful Means, Peace and Conflict, Development and Civilization. London: PRIO, SAGE Publications.

2000. Local Authorities as Peace Factors/Actors/Workers. Journal of World-Systems Research. (online), Vi, 3, Fall/Winter 2000, 860-872, (http://csf.colorado.edu/jwsr, diakses pada 15 Oktober 2011).

2004. Transcend and Transform, An Introduction to Conflict Work. London: Pluto Press. 2007. A Mini Theory of Peace. (online),

(www.transnational.org, diakses pada 10 Agustus 2010) 2007. Learning from Gandhi: Towards a nonviolent world order. New Delhi: The Satyagraha Centenary. (online), (www.transnasional.org, diakses pada 12 Februari 2011). 2009. Johan Galtung's view from Europe: Women and Men, Peace and Security. (online), (http:// www. peaceactionme.org, diakses pada 10 Agustus 2010). 2009. European Commission Speech, Making the Difference: Strengthening the Capacities to Respond to Crises and Security Threats. Brussels. (Online), (http:// www. peaceactionme.org/blog/johan-galtung-s-view-europewomen-and-men-peace-and-security, diakses pada 11 januari 2011).

2010. Women and the 21st century. (online), (https:// www.transcend.org/tms/2010/12/women-and-the-21stcentury/, diakses pada 15 Januari 2010).

2010. 'Violence Typology'. Peace Education Basic Course 2. (online), (http://www.dadalos.org/frieden_int/grundkurs_2/ typologie.htm, diakses pada 11 September 2010).

Gen C Magazine, Interviews with Johan Galtung. (online), (http:// www.generation-c.org/galtung_interview.html/2010 diakses pada 7 Februari 2011).

Jamil, M Muchsin. 2006. Resolusi Konflik: Berbagai Model. (online), (http://wmc-iainws.com/home.php, diakses pada 25 Agustus 2010).

Mas'oed, Mochtar. 1992. Galtung, Perspektif Kritis, dan Hubungan Internasional, Sebuah Pengantar, dalam I Marsana Windhu. 1992. Kekuasaan dan Kekerasan Menurut Johan Galtung. Jogjakarta: Kanisius.

Mies, Maria. 1993. "The Need for a New Vision: The Subsistence
Perpektive", dalam Mies dan Shiva. Ecofeminisme, London: Zed.

1993. "White Man's Dillema: His Search for What He Has Destroyed" dalam Mies dan Shiva. Ecofeminism. London, Zed.

Muthien, Bernedette. 2003. Engendering Security. (online) (http:// www.engender.org.za/publications.html diakses pada 11 Januari 2011).

Nur Syam. 2005. Islam Pesisir. Yogyakarta: LkiS.

Pilcher, Jane \& Whelehan, Imelda. 2004. 50 Key Concepts in Gender Studies, London: SAGE Publication.

Salmi, Jamil. 1993. Violence and Democratic Society, New Approach to Human Right. London: Zed Book.

Windhu, I Marsana. 1992. Kekuasaan dan Kekerasan Menurut Johan Galtung. Yogyakarta: Kanisius.

Johan Galtung, Honorary Award 1987. (online), (http:// www.rightlivelihood.Org/galtung.pdf, diakses pada 1 Oktober 2010).

Johan Galtung in Brief. (online), (http://www.brad.ac.uk/acad/ confres/dislearn/galtung.html, diakses pada 11 Januari 2011).

Addressing Gender-Based Violence Through Community Empowerment. (online), (http://www.lac.org.na/publications/ alphabet.html, diakses pada 5 Oktober 2010). 